\title{
Study of a family in the province of Matera presenting with glucose-6-phosphate dehydrogenase deficiency and Gilbert's syndrome
}

\author{
DOMENICO DELL'EDERA ${ }^{1}$, ANNUNZIATA ANNA EPIFANIA ${ }^{1}$, ANDREA TINELLI $^{5}$, MANUELA LEO $^{1}$, \\ ANTONIO NOVELLI ${ }^{2}$, ANTONIO DI TRANI ${ }^{1}$, GIUSEPPE BARRANO ${ }^{3}$, MARTA BERTOLI ${ }^{3}$, \\ ELEONORA MAZZONE $^{1}$, MICHELE BENEDETTO ${ }^{1}$, DAMIAN SIMONA ${ }^{4}$ and ANTONIO MALVASI ${ }^{6}$
}

\begin{abstract}
${ }^{1}$ Unit of Cytogenetic and Molecular Genetics, Madonna delle Grazie Hospital, Matera; ${ }^{2}$ Mendel Laboratory IRCCS Hospital, San Giovanni Rotondo (FG); ${ }^{3}$ Unit of Medical Genetics, San Pietro FBF Hospital, Rome, Italy; ${ }^{4}$ Vasile Goldis University, Arad, Romania; ${ }^{5}$ Obstetrics and Gynecology Department, V. Fazzi Hospital, Lecce;

${ }^{6}$ Obstetrics and Gynecology Department, Santa Maria Hospital, Bari, Italy
\end{abstract}

Received November 23, 2011; Accepted February 28, 2012

DOI: $10.3892 / \mathrm{mmr} .2012 .830$

\begin{abstract}
Glucose-6-phosphate dehydrogenase (G6PD) deficiency, a recessive $\mathrm{X}$-linked trait, is the most common enzyme deficiency in the world. The most devastating clinical consequence of this deficit is severe neonatal jaundice, which results in sensorineural deficit, and severe haemolytic anemia. However, patients may be asymptomatic. The most common clinical sign is hyperbilirubinemia $(\mathrm{h} \uparrow)$, that is also related to Gilbert's syndrome, a condition associated with the promoter polymorphism of the UDP-glucuronosyltransferase 1 (UGT1A1) gene. The aim of this study was to underline (as is usually done by DNA molecular analysis) to detect and to clarify the genetic deficiency that is the reason of the disorder in question. In this study, different techniques were applied to analyse a family of four individuals presenting with hyperbilirubinemia: bilirubinic dosage, electrophoresis and enzymatic activity dosage of G6PD; molecular analysis of the UGT1A promoter to detect a thymine-adenine (TA) insertion, that causes the $\left[\mathrm{A}(\mathrm{TA})_{7} \mathrm{TAA}\right]$ mutation. The results showed that in certain cases, the presence of hyperbilirubinemia is not only associated with G6PD deficiency, but may be caused by the co-presence of a mutation in the UGTAl promoter related to Gilbert's syndrome. As being affected by these two conditions predisposes to adverse effects towards certain drug treatments, it is advisable to study the UGTA1 gene before prescribing drugs for specific antineoplastic or retroviral tratment. We emphasize that investigating
\end{abstract}

Correspondence to: Dr Domenico Dell'Edera, Unit of Cytogenetic and Molecular Genetics, 'Madonna delle Grazie' Hospital, Matera, Italy

E-mail: ducati98@libero.it

Key words: Gilbert's syndrome, glucose-6-phosphate dehydrogenase deficiency, hemolysis, hyperbilirubinemia, irinotecan, atazanavir both the UGT1A gene and G6PD activity is the most reliable way to make a correct differential diagnosis.

\section{Introduction}

Glucose-6-phosphate dehydrogenase (G6PD) deficiency is a common X-linked recessive $(1,2)$ human hereditary disease, characterized by very low levels of the enzyme, G6PD. The genetic variability is considerable, more than 440 variants of the enzyme have been described (3), distinguishable by their biochemical and functional characteristics, of which 86 are classified as polymorphic. In Italy, the highest incidence has been observed in areas where malaria was endemic, as although not fully understood, G6PD deficiency protects against severe malaria (Plasmodium falciparum) $(4,5)$.

Basilicata, a region of Southern Italy, is no exception to this and in males from the province of Matera, there is an incidence of G6PD deficiency ranging from 2.8 to $7 \%$ (6). Studies on the chemical and physical properties of the enzyme, and especially its electrophoretic mobility, have enabled us to distinguish two main varieties: a faster version called ' $\mathrm{A}$ ' and another slower variation called ' $\mathrm{B}$ '. The $\mathrm{B}$ version is also called 'common type (wild-type)', as it is the most common, while type A is common to African populations.

Depending on the level of enzyme activity and clinical manifestations of G6PD, variants are divided into five classes (I, II, III, IV and V). Class increases with increasing level of enzyme activity and less severe clinical manifestations (Table I).

Gilbert's syndrome is a form of chronic moderate hyperbilirubinemia caused by decreased hepatic bilirubin glucuronidation by UDP-glucuronosyl transferase 1 (UGT1A1). In different populations, there are a number of thymine-adenine (TA) repeats varying from 5 to 8 , with an inverse correlation between promoter activity and number of TA repetitions: $\mathrm{A}(\mathrm{TA})_{8} \mathrm{TAA}$ promoter with reduced activity, $\mathrm{A}(\mathrm{TA})_{7} \mathrm{TAA}$ promoter with reduced activity (UGT1A1*28), A(TA) ${ }_{6}$ TAA wild-type and $\mathrm{A}(\mathrm{TA})_{5} \mathrm{TAA}$ promoter with increased activity. 
Most patients presenting with this disease are homozygous $\left[\mathrm{A}(\mathrm{TA})_{7} \mathrm{TAA} / \mathrm{A}(\mathrm{TA})_{7} \mathrm{TAA}\right]$ for a TA insertion in the TATA box of the UGTIAl gene promoter and have a 70\% reduction in the glucuronidation of bilirubin $(7,8)$. Hyperbilirubinemia may increase under certain conditions, such as prolonged fasting, especially fats, fever or infections. Besides jaundice, several patients may also develop abdominal pain, loss of appetite and fatigue. Despite liver disorders, clinical examination and the morphology of the liver are normal (9). Therefore, we may speculate that the presence of jaundice is a condition that is always present in the case of Gilbert's disease, but it may be present even in the presence of G6PD deficiency.

D.D. (58 years of age) was admitted to our attention on July 2010 to be examined for G6PD deficiency. The request was motivated by the fact that D.D., following ingestion of two tablets of $500 \mathrm{mg}$ acetylsalicylic acid $8 \mathrm{~h}$ apart from each other, had presented with the appearance of dark urine, fatigue, fever and hyperbilirubinemia, signs of haemolitic anemia. Previous laboratory clinical tests performed indicated the constant presence of unconjugated hyperbilirubinemia, which could be partially explained by the suspicion of G6PD deficiency. In addition, family history showed that unconjugated hyperbilirubinemia was also present in the mother (P.M.), son (D.S.) and daughter (D.G.) (Table II). For these reasons, all members of the family were analyzed.

\section{Materials and methods}

The following tests were performed on all family members: A full blood exam with Sysmex XE 2100 (Dasit Cornaredo, Milan, Italy), with evaluation of the $\mathrm{Hb}, \mathrm{MCH}, \mathrm{MCV}, \mathrm{MCH}$ and $\mathrm{MCHC}$, as well as a laboratory test of total bilirubin levels, direct and indirect. Other tests included:

G6PD enzymatic activity. G6PD activity was measured as the difference between the activity of G6PD enzymes and 6 phosphogluconate dehydrogenase (6PGD). 6PGD enzyme activity was used as the internal reference. The association between the two enzymes is therefore an absolute measure that reflects the least individual variation of erythrocyte $\mathrm{Hb}$ content, the number of erythrocytes, the number of reticulocytes and leukocytes (G6PD/6PGD reference values: $>1.22$ normal activity; $0.95-1.22$ normal activity with normal MCV; 0.95-1.22 normal activity with low MCV; 0.30-0.95 intermediate level; 0.01-0.30 deficient activities).

G6PD electrophoretic mobility. The G6PD electrophoretic mobility was evaluated with electrophoresis of hemolysates on cellulose acetate strips in $\mathrm{pH} 8.6$ buffer solution (Tris- $\mathrm{HCl}$, borate, EDTA). After a run at $150 \mathrm{~V}$ for $90 \mathrm{~min}$, the strips were stained with a mixture composed of Tris-HCl (1 M), G6PD $(10 \mathrm{ng} / \mathrm{ml}), \mathrm{NADP}(5 \mathrm{ng} / \mathrm{ml}), \mathrm{MgCl}_{2}(1 \mathrm{M})$, NBT $(2 \mathrm{mg} / \mathrm{ml})$ and PMS $(2 \mathrm{ng} / \mathrm{ml})$ and incubated for $10 \mathrm{~min}$ at $37^{\circ} \mathrm{C}$ in the dark (10). On the basis of this method, an altered enzymatic state will have normal, fast or slow electrophoretic mobility.

Molecular characterization. After DNA isolation starting from $25 \mu \mathrm{l}$ of blood, using the extraction kit of Promega Italy S.r.l. (DNA IQ ${ }^{\mathrm{TM}}$ System, cod. C6701), polymerase chain reaction (PCR) analysis was performed on the mutation-containing DNA segment. We studied the four mutations which appear to be the most frequent in Southern Italian regions: the Mediterranean, the Seattle, the $\mathrm{A}^{-}$and the Montalbano variants.
Table I. Classification based on UGTIA enzymatic activity and its clinical manifestations.

\begin{tabular}{llll}
\hline Grade & $\begin{array}{c}\text { Enzyme } \\
\text { activity }\end{array}$ & \multicolumn{1}{c}{$\begin{array}{c}\text { Clinical } \\
\text { manifestations }\end{array}$} & \multicolumn{1}{c}{ Example } \\
\hline I & Various & AECnS, IN & Santiago \\
II & $<10$ & AEA, IN & Mediterranean \\
III & $10-60$ & AEA, IN & $\mathrm{A}^{-}$; Montalbano \\
IV & $60-150$ & No & $\mathrm{A}^{+}$ \\
V & Augmented & No & Hektoen \\
\hline
\end{tabular}

AEcNS, chronic non-spherocytic hemolytic anemia; AEA, acute hemolytic anemia following ingestion of drugs, viral infections or fava beans. IN, neonatal jaundice.

Table II. Levels of total bilirubin, direct and indirect of the analyzed family members.

\begin{tabular}{lccc}
\hline & $\begin{array}{c}\text { Total } \\
\text { bilirubin }\end{array}$ & $\begin{array}{c}\text { Indirect } \\
\text { bilirubin }\end{array}$ & $\begin{array}{c}\text { Direct } \\
\text { bilirubin }\end{array}$ \\
\hline D.D. (M) & $1.9 \mathrm{H}$ & 0.2 & $1.7 \mathrm{H}$ \\
P.M. (F) & $1.4 \mathrm{H}$ & 0.1 & $1.3 \mathrm{H}$ \\
D.G. (F) & $2.4 \mathrm{H}$ & 0.3 & $2.1 \mathrm{H}$ \\
D.S. (M) & $2.9 \mathrm{H}$ & 0.4 & $2.5 \mathrm{H}$ \\
Normal range (mg/dl) & $0.2-1.2$ & $0.0-0.4$ & $0.2-0.8$ \\
\hline
\end{tabular}

$\mathrm{M}$, male; $\mathrm{F}$, female.

Table III. Molecular features of the studied mutations.

Location of point mutations in four different G6PD variants

\begin{tabular}{lrrr}
\hline Exon & $\begin{array}{c}\text { G6PD } \\
\text { variant }\end{array}$ & $\begin{array}{c}\text { Nucleotide } \\
\text { change }\end{array}$ & $\begin{array}{r}\text { Amino acid } \\
\text { substitution }\end{array}$ \\
\hline Mediterranean & 11 & $563 \mathrm{C}>\mathrm{T}$ & $188 \mathrm{Ser}>\mathrm{Phe}$ \\
$\mathrm{A}^{-}$ & 6 & $202 \mathrm{G}>\mathrm{A}$ & $68 \mathrm{Val}>\mathrm{Met}$ \\
Seattle & 9 & $844 \mathrm{G}>\mathrm{C}$ & $282 \mathrm{Asp}>\mathrm{His}$ \\
Montalbano & 12 & $854 \mathrm{G}>\mathrm{A}$ & $285 \mathrm{Arg}>\mathrm{His}$ \\
\hline
\end{tabular}

The molecular features of the mutations studied are listed in Table III. For the Mediterranean variant, a 267-bp fragment of exon VI containing the $563 \mathrm{C} \rightarrow \mathrm{T}$ mutation was amplified; for the Seattle and Montalbano variants, the amplified fragment was a 646-bp fragment, including exons VII and VIII (844 $\mathrm{G} \rightarrow \mathrm{C}$ and $854 \mathrm{G} \rightarrow \mathrm{A}$ at exon VIII). For the $\mathrm{A}^{-}$mutation, a 1,131-bp fragment was amplified corresponding to exons III-IV and $\mathrm{V}$ for recognition of the $202 \mathrm{G} \rightarrow \mathrm{A}$ mutation at exon IV responsible for the enzymatic deficiency. The sequence of the primers for amplification is listed in Table IV. For the Mediterranean variant, the amplified DNA was cleaved into two fragments of 138 and 116 bp. The MboII specific restriction site is created only in the presence of a mutation resulting in fragments of 
Table IV. Sequence of the primers for amplification of the DNA fragment containing the studied mutations.

\begin{tabular}{lll}
\hline Primer & \multicolumn{1}{c}{ Sequence } & \multicolumn{1}{c}{ Variant } \\
\hline R6 & 5'-GGTGAGGCTCCTGAGTACCA-3' & Mediterranean \\
L1 & 5'-AGCTGTGATCCTCACTCCCC-3' & Mediterranean \\
R8 & 5'-TCACAGATGGGCCTGCGACA-3' & Seattle and Montalbano \\
GdL7 & 5'-CCACAGAGGCCCAAGGTCAG-3' & Seattle and Montalbano \\
L3 & 5'-CGTGTCCCCAGCCACTTCTA-3' & A' \\
R5 & 5'-CACGCTCATAGAGTGGTGGG-3' & A $^{-}$ \\
\hline
\end{tabular}

138 and 116 bp. The amplified fragment of G6PD from a normal subject does not contain this cleavage site. The Seattle mutation is in exon VIII and clears the cleavage site for the $D d e I$ enzyme. Restriction of the normal amplified fragment yields five fragments of 211, 157, 130, 101 and $79 \mathrm{bp}$, while the restriction pattern of the mutated sequence produces four fragments of 211, 180, 157 and $130 \mathrm{bp}$. The mutation therefore produces a new 180-bp band resulting from the lack of cleavage of the 101- and 79-bp bands. The $202 \mathrm{G} \rightarrow \mathrm{A}$ mutation in exon IV, responsible for variation A-, is recognized by the enzyme NlaIII; in a normal subject, the restriction pattern is the following: 419, 346, 178, 102 and $86 \mathrm{bp}$. In the presence of the mutation, the 346-bp fragment is cleaved into two fragments of 223 and $123 \mathrm{bp}$. In the Montalbano variant, the enzyme NlaIII yields a restriction pattern of 424, 118, 104, 40, 37 and 5 bp compared to a normal pattern of 424, 118, 104 and 82 bp. In the case of $\mathrm{A}^{-}$and Mediterranean variants, enzymatic restriction was confirmed with ASO-probes. Then, the amplified correspondent of the DNA segments containing the mutation was denatured with $1 \mathrm{~N} \mathrm{NaOH}$ and subjected to the dot-blot technique. Subsequently, the membrane was hybridized with specific wild-type and mutant 5' $\gamma$-32P-ATPlabeled oligonucleotides. The oligonucleotide sequences corresponding to the two variants examined are the following: for the Mediterranean variant, a wild-type oligonucleotide 5'-ACCACATCTCCTCCCTGTT-3' with a $58^{\circ} \mathrm{C}$ hybridization temperature and a $60^{\circ} \mathrm{C}$ washing temperature, and a mutant oligonucleotide 5'-AACAGGCACAAGATGTGGT-3' with a $56^{\circ} \mathrm{C}$ hybridization temperature and a $58^{\circ} \mathrm{C}$ washing temperature; for the A- variant, a wild-type oligonucleotide 5'-AGCCACATGAATGCCCTCC-3' with a $60^{\circ} \mathrm{C}$ hybridization temperature and a $62^{\circ} \mathrm{C}$ washing temperature, and a mutant oligonucleotide 5'-GGAGGGGCATCCATGTGGCT-3' with a $66^{\circ} \mathrm{C}$ hybridization temperature and a $68^{\circ} \mathrm{C}$ washing temperature. The hybridization was visualized by autoradiography at $80^{\circ} \mathrm{C}$ for $1-2 \mathrm{~h}$. This method permits the analysis of a large number of samples simultaneously.

Genotyping by direct sequencing of the UGTA1 gene. The TATA box region of the UGT1Al gene promoter was amplified using specific primers (5'-AAGTGAACTCCCTGCTACCTT-3' and 5'-CCACTGGGATCAACAGTATCT-3') synthesized and provided by Invitrogen. PCR was prepared in $25 \mu 1$ [1.5 mmol/1 magnesium chloride $\left(\mathrm{MgCl}_{2}\right), 100 \mathrm{mmol} / \mathrm{l}$ deoxynucleotides (dNTPs), $80 \mathrm{nmol} / 1$ 'primer', 0.5 IU DNA polymerase (Taq polymerase) and $5 \mu \mathrm{l}$ DNA] and amplified on a thermocycler
'Eppendorf Mastercycler' under the following conditions: $94^{\circ} \mathrm{C}$ for $10 \mathrm{sec}$, followed by 30 cycles of three steps $\left(94^{\circ} \mathrm{C}\right.$ for $30 \mathrm{sec}, 58^{\circ} \mathrm{C}$ for $40 \mathrm{sec}$ and $72^{\circ} \mathrm{C}$ for $30 \mathrm{sec}$ ). Taq polymerase, $\mathrm{MgCl}_{2}$ and dNTPs were supplied by Applied Biosystems. The reaction sequence (forward and reverse) was prepared on the amplified products using the Big Dye Terminator VI.I Cycle Sequencing kit (Applied Biosystems) and the same primer of PCR reactions, but at a final concentration of $0.32 \mu \mathrm{M}$.

Direct sequencing was obtained by automatic sequencer ABI PRISM 310 Applied Biosystems and the results were analyzed using the Sequencing Analysis software.

\section{Results}

Samples from the four family members (father: D.D., mother: P.M., son: D.S. and daughter: D.G.) were analyzed by different methods and techniques.

D.D. (the father) had an intermediate activity of G6PD deficiency (Table V) and an electrophoretic pattern which showed $80 \%$ of normal migration rate (Fig. 1) associated to $\mathrm{h} \uparrow$ (indirect bilirubin, $1.7 \uparrow \mathrm{mg} / \mathrm{dl}$; normal range, $0.2-0.8 \mathrm{mg} /$ dl) and molecular evidence of mutation in the UGT1A gene in heterozygosity, showing a nucleotide substitution in exon 8 (854 G>A; Montalbano) (Table III) with an electrophoretic activity of class III (Table I).

P.M. (the mother) had a normal G6PD activity (1.38; Table V), and an electrophoretic pattern which showed a migration rate equal to the normal variation (G6PDB) (Fig. 1), associated to $\mathrm{h} \uparrow$ (indirect bilirubin, $1.3 \uparrow \mathrm{mg} / \mathrm{dl}$ ) and molecular evidence of a heterozygous mutation in the UGT1A gene.

D.S. (the son) had a normal G6PD activity (1.42; Table V), and an electrophoretic pattern which showed a migration rate equal to the normal variation (G6PDB) (Fig. 1) associated to $\mathrm{h} \uparrow$ (indirect bilirubin, $2.50 \uparrow \mathrm{mg} / \mathrm{dl}$ ) and Gilbert's syndrome (molecular evidence of a homozygous mutation in the UGT1A gene).

D.G. (the daughter) had an intermediate G6PD deficiency (0.63; Table V), despite being female, as layonization was responsible for the disorder manifestation. The electrophoretic pattern showed a double band, one of paternal origin (with a migration rate equal to $80 \%$ of normal) and the other of maternal origin (with a migration rate equal to the normal variation G6PDB) (Fig. 1). From a genetic perspective, the daughter had a gene for G6PD normal (maternal origin) and one mutated gene (of paternal origin $854 \mathrm{G}>\mathrm{A}$; Montalbano). We did did not need to carry out a molecular genetic analysis 
Table V. Enzyme G6PD activity, elecrophoretic speed, mutation and mean corpuscular volume (MCV) of the analyzed family members.

\begin{tabular}{|c|c|c|c|c|c|}
\hline & $\begin{array}{l}\text { Enzyme } \\
\text { activity }\end{array}$ & $\begin{array}{l}\text { Normal range unit: } \\
\text { G6PD/6PGD }\end{array}$ & $\begin{array}{l}\text { Electrophoretic } \\
\text { speed }\end{array}$ & $\begin{array}{c}\text { Mutation gene } \\
\text { G6PD }\end{array}$ & $\begin{array}{l}\mathrm{MCV} \\
(80-97)\end{array}$ \\
\hline D.D. (M) & 0.52 & $\begin{array}{l}>1.22 \\
(0.95-1.22 \text { normal activity } \\
\text { with normal MCV) }\end{array}$ & $\begin{array}{l}\text { Speeds of up to } 80 \% \text { of } \\
\text { normal (=G6PDB) }\end{array}$ & $854 \mathrm{G}>\mathrm{A}$ & 85.4 \\
\hline P.M. (F) & 1.38 & $\begin{array}{l}0.95-1.22 \\
\text { (intermediate level } \\
\text { with a low MCV) }\end{array}$ & G6PDB & - & 92.2 \\
\hline D.G. (F) & 0.63 & $\begin{array}{l}0.30-0.95 \\
\text { (intermediate level) }\end{array}$ & $\begin{array}{l}\text { Presence of two electrophoretic bands } \\
\text { corresponding to: G6PDB/Gd- } \\
\text { with a speed of } 80 \% \text { of normal (=G6PDB) }\end{array}$ & $\begin{array}{l}854 \mathrm{G}>\mathrm{A} / \\
\text { wild-type }\end{array}$ & 81.6 \\
\hline D.S. (M) & 1.42 & $\begin{array}{l}0.01-0.30 \\
\text { (deficient activity) }\end{array}$ & G6PDB & - & 83.0 \\
\hline
\end{tabular}

M, male; F, female.

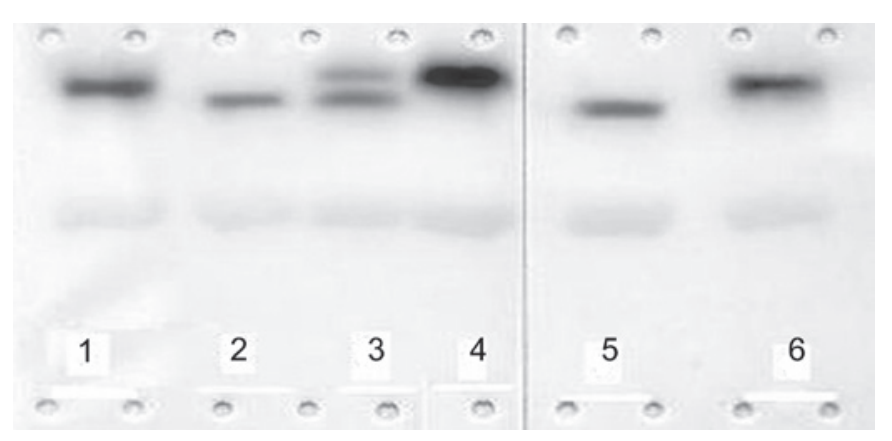

Figure 1. G6PD electrophoresis. Wells 1 and 6, electrophoresis of D.S. Presence of the band associated with G6PDB. Wells 2 and 5, electrophoresis of D.D. Electrophoretic pattern showing $80 \%$ of normal migration rate. Well 3, electrophoresis of D.G. Electrophoretic pattern showing a double band, one of paternal origin (with a migration rate equal to $80 \%$ of normal) and the other of maternal origin (with a migration rate equal to the normal variation G6PDB). Well 4, electrophoresis of P.M. Presence of the band associated with G6PDB.

of the G6PD gene for the daughter. Morever, this is a case of patient with Gilbert's syndrome (molecular evidence of a homozygous mutation in the UGTIA gene).

This study shows that there are cases in which the presence of $h \uparrow$ is not associated with G6PD deficit, but, such as in the analyzed family, is caused by the presence of a mutation in the UGTA1 promoter, related to Gilbert's syndrome.

For this reason, it is always advisable to perform a molecular analysis of the UGTAl gene, especially in patients who, for health reasons, must undergo drug treatment, such as antineoplastic or retroviral. We emphasize that investigating both UGT1A gene and G6PD activity is crucial in order to obtain a differential diagnosis.

Therefore, it was evident that the isolated elevation of indirect bilirubin in all members of the family was not due to a single cause, a deficiency of G6PD, as suspected at first after the diagnosis of the father.

Table II shows the levels of total bilirubin, direct and indirect, of the family members in question. The molecular

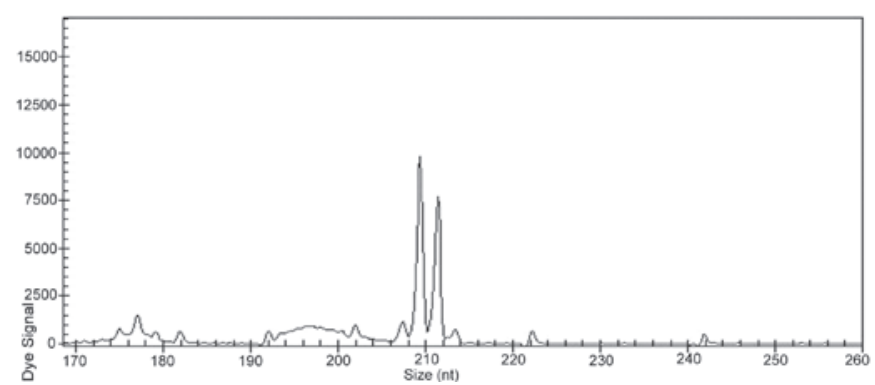

Figure 2. UGT1A1 gene promoter showed that D.D. and P.M. had the heterozygous mutation, insertion of a dinucleotide 'thymine-adenine (TA) repeat' $\left[\mathrm{A}(\mathrm{TA})_{6} \mathrm{TAA} / \mathrm{A}(\mathrm{TA})_{7} \mathrm{TAA}\right]$.

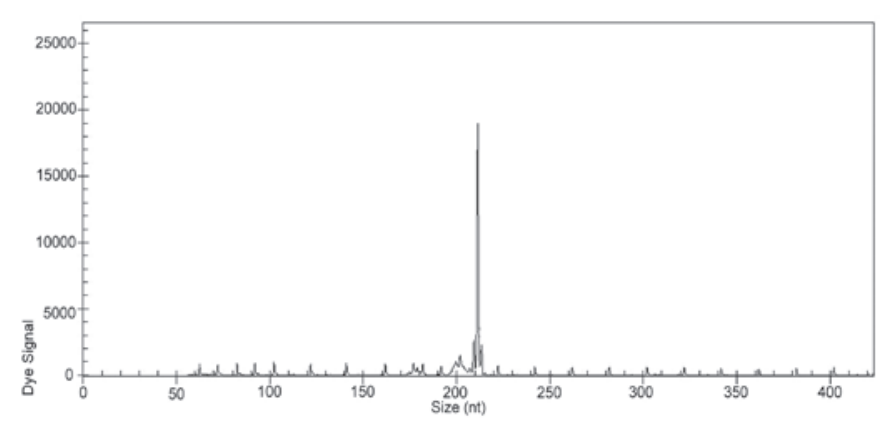

Figure 3. The molecular study of the children (D.S. and D.G.) in the UGT1A1 gene promoter showed that they were homozygous [A(TA) ${ }_{7}$ TAA/A(TA) 7 TAA], the dinucleotide 'thymine-adenine (TA) repeat' in the TATA box of the promoter gene (UGT1A1 ${ }^{*} 28$ ) leading to reduced transcription and expression of Gilbert's syndrome.

analysis of the UGT1A1 gene promoter showed that D.D. and P.M. had the heterozygous mutation, an insertion of a dinucleotide 'TA repeat' [A(TA) 6 TAA/A(TA) 7 TAA](Fig. 2). The molecular analysis of the the UGT1A1 gene promoter in the children (D.S. and D.G.) showed that they were homozygous $\left[\mathrm{A}(\mathrm{TA})_{7} \mathrm{TAA} / \mathrm{A}(\mathrm{TA})_{7} \mathrm{TAA}\right]$, the dinucleotide TA repeat 
in the TATA box of the promoter gene (UGT1A1*28) leading to reduced transcription and expression of Gilbert's syndrome (Fig. 3).

\section{Discussion}

Gilbert's syndrome has always been considered a benign condition not associated with chronic liver dysfunction. However, recent studies have shown an association of the UGTIAl gene with the toxicity of anticancer (irinotecan) $(11,12)$ and retroviral drugs (atazanavir) $(13,14)$.

In particular, in patients treated with irinotecan, the presence of the variant UGT1A1*28 leads to increased levels of active metabolite 7-ethyl-10-idrossicamptotecina causing sideeffects (myelosuppression, diarrhea). In case of treatment with atazanavir, which does not seem to be an important substrate for glucuronidation, but is still able to inhibit UGT1A1, the presence of the variant UGT1A1*28 leads to a further decrease in enzyme activity resulting in major hyperbilirubinemia (15).

The analysis of polymorphism of the UGT1Al gene may therefore be useful from a clinical point of view to identify patients who may most benefit from drug treatment or to predict serious side-effects.

This study contends that, in some cases, the identification of subjects with a deficiency of erythrocyte G6PD or with Gilbert's jaundice, in itself does not justify the presence of jaundice. In certain cases, the identification of subjects with Gilbert's jaundice may present particular difficulties in interpretation by evaluating only the biochemical and hematological findings. For this reason, in the presence of chronic asymptomatic jaundice, the molecular study of the UGTAl gene is always advisable, even if the familial diagnosis seems to be clear and established as G6PD deficiency, especially in patients who, for health reasons, must undergo anticancer (irinotecan) or retroviral (atazanavir) drug treatments. In addition, G6PD enzyme activity cannot be a predictor of the severity of clinical conditions. Molecular analysis is able to characterize the clinical phenotype, but it is not a predictor of hemolytic crisis.

\section{References}

1. Martini G, Toniolo D, Vulliamy T, Luzzatto L, Dono R, Viglietto G, Paonessa G, D'Urso M and Persico MG: Structural analysis of the X-linked gene encoding human glucose-6phosphate dehydrogenase. EMBO J 5: 1849-1855, 1986.
2. Takizawa T, Huang I, Ikuta T and Yoshida A: Human glucose-6phosphate dehydrogenase: primary structure and cDNA cloning. Proc Natl Acad Sci USA 8: 4157-4161, 1986.

3. Nkhoma ET, Poole C, Vannappagari V, Hall SA and Beutler E: The global prevalence of glucose-6-phosphate dehydrogenase deficiency: a systematic review and meta-analysis. Blood Cells Mol Dis 42: 267-278, 2009.

4. Beutler E: G6PD deficiency. Blood 84: 3613-3636, 1994.

5. Luzzatto L, Usanga EA and Reddy S: Glucose-6-phosphate dehydrogenase deficient red cells: resistance to infection by malarial parasites. Science 164: 839-842, 1969.

6. Viglietto G, Montanaro V, Calabrò V, Vallone D, D'Urso M, Persico MG and Battistuzzi G: Common G6PD variants from the Italian population: biochemical and molecular characterization. Ann Hum Genet 54: 1-15, 1990.

7. Bosma PJ, Chowdhury JR, Bakker C, Gantla S, de Boer A, Oostra BA, Lindhout D, Tytgat GNJ, Jansen PLM, Oude Elferink RPJ and Chowdhury NR: The genetic basis of the reduced expression of bilirubin UDP-glucuronosyltransferase 1 in Gilbert's syndrome. N Engl J Med 333: 1171-1175, 1995.

8. Hsieh TY, Shiu TY, Huang SM, Lin HH, Lee TC, Chen PJ, Chu HC, Chang WK, Jeng KS, Lai MM and Chao YC: Molecular pathogenesis of Gilbert's syndrome: decreased TATAbinding protein binding affinity of UGT1A1 gene promoter Pharmacogenet Genomics 17: 229-236, 2007.

9. Feverey J: Pathogenesis of Gilbert's syndrome. Eur J Clin Invest 11: 417-418, 1981.

10. Luzzato L and Mehta AB: Glucose-6-phosphate dehydrogenase deficiency. In: Scriver CR, Beaudet AL, Sly WS and Valle D (eds.): The Metabolic Basis of Inherited Disease. II. Mc Graw-Hill, New York, pp3367-3398, 1995.

11. Ando Y, Saka H, Asai G, Sugiura S, Shimokata K and Kamataki T: UGT1A1 genotypes and glucuronidation of $\mathrm{SN}-38$, the active metabolite of irinotecan. Ann Oncol 9: 845-847, 1998

12. Rouits E, Boisdron-Celle M, Dumont A, Guérin O, Morel A and Gamelin E: Relevance of different UGT1A1 polymorphism inirinotecan-induced toxicity: a molecular and clinical study of 75 patients. Clin Cancer Res 10: 5151-5159, 2004.

13. Lankisch TO, Moebius U, Wehmeier M, Behrens G, Manns MP, Schmidt RE and Strassburg CP: Gilbert's disease and atazanavir: from phenotype to UDP-glucuronosyltransferase haplotype. Hepatology 44: 1324-1332, 2006.

14. Rotger M, Taffe P, Bleiber G, Gunthard HF, Furrer H, Vernazza P, Drechsler H, Bernasconi E,Rickenbach M, Telenti A and Swiss HIV: Cohort Study: Gilbert syndrome and the development of antiretroviral therapy-associated hyperbilirubinemia. J Infect Dis 192: 1381-1386, 2005.

15. Zhang D, Chando TJ, Everett DW, Patten CJ, Dehal SS and Humphreys WG: In vitro inhibition of UDP glucuronosyltransferase by atazanavir and other HIV protease inhibitor and the relationship of this property to in vivo bilirubin glucuronidation. Drug Metab Dispos 33: 1729-1739, 2005. 